\title{
PENGARUH KECUKUPAN MODAL TREHADAP MANAJEMEN RISIKO LIKUIDITAS BANK PERKREDITAN RAKYAT (Studi Empiris Pada Bank Prekreditan Rakyat di Kota Tangerang)
}

\author{
Hendra Galuh Febrianto, S.E.I., M.Akun \\ Rabitha Fazira, S.E., M.M \\ Fakultas Ekonomi dan Bisnis \\ Universitas Muhammadiyah Tangerang
}

\begin{abstract}
Abstrak
Penelitian ini bertujuan untuk menganalisis manajemen risiko likuiditas BPR di Kota Tangerang melalui kecukupan modal dengan tujuan akhir merekomendasikan kebijakan untuk memperbaiki manajemen risiko likuiditas BPR. Jenis penelitian ini menggunakan jenis penelitian eksplanatori dengan pendekatan kuantitatif. Analisis data dalam penelitian menggunakan analisis regresi linier berganda pada panel data laporan keuangan 20 BPR di Tangerang dari tahun 2012 sampai 2016. Ada dua kelompok variabel yang digunakan dalam penelitian ini. Variabel terikat dalam penelitian ini adalah risiko likuiditas diukur dengan current ratio. kecukupan modal diukur dengan capital adequacy ratio ( CAR ). Hasil penelitian ini menunjukkan bahwa kecukupan modal berpengaruh signifikan terhadap Manajemen Risiko Likuiditas pada Bank Perkreditan Rakyat..
\end{abstract}

Kata Kunci : Kecukupan Modal dan Manajemen Risiko Likuiditas

\section{A. PENDAhULUAN}

Sejak awal tahun hingga Mei 2016 sudah ada lima BPR yang tutup, karena catatan keuangan yang buruk, khususnya rasio kecukupan modal (CAR) mencapai negatif 209,79 persen. Banyaknya kredit macet menjadi alasan penutupan ini (www.merdeka.com diakses 15 April 2017). Ditambah lagi dengan permasalahan sumber dana. Pada Rakernas dan Seminar Nasional Perhimpunan Bank Perkreditan Rakyat Indonesia di Pontianak, 26 Oktober 2016, OJK menyatakan bahwa dari jumlah BPR sebanyak 1.797 sebagian besar (1.184 BPR/68\%) memiliki modal inti yang terbatas (di bawah Rp 6 M) dan memiliki kinerja cenderung buruk. Dan biaya dana terbesar bersumber dari dana mahal bunga deposito dan pinjaman dari bank lain (tabungan $5,74 \%$, deposito $9,06 \%$, linkage $12,10 \%$ ).

Barrel dkk. (2009) menekankan pentingnya likuiditas dan mengkritik regulator yang berpihak hanya pada kecukupan modal. Dari berbagai episode krisis perbankan, jelas bahwa likuiditas memainkan peran yang lebih penting daripada modal.Masalah utama BPR adalah bagaimana mengelola likuiditas secara efisien. Risiko likuiditas dapat dilihat dari dua perspektif. Dari perspektif aset, ketidakmampuannya untuk membiayai 
kenaikan aset atau ketidakmampuan untuk melikuidasi aset tanpa menimbulkan kerugian. Dari perspektif pertanggungjawaban, risikolikuiditas adalah ketidakmampuan membayar kewajiban atau ketidakmampuan bank untuk meminjam dengan biaya yang wajar.

Dengan kata lain, adalah risiko tidak mampu menghasilkan aset likuid seperti kas atau surat berharga untuk melunasi semua kewajiban atau komitmen. Dalam prakteknya, risiko likuiditas adalah ketidakmampuan bank untuk melunasi semua kewajibannya pada waktunya.

Saat ini, BPR menerapkan pendekatan individual untuk manajemen likuiditas. Setiap BPR memberikan rasio likuiditas yang lebih tinggi untuk menjamin uang tunai yang tersedia saat deposan menarik tabungan mereka. Di Indonesia rasionya sekitar $29 \%$. Hal itu membuat BPR kurang mampu memberikan pembiayaan untuk bisnis, karena mereka juga harus memperhatikan risiko likuiditas. Pengelolaan likuiditas yang lebih baik akan memperbaiki kinerja BPR. Oleh karena itu, penelitian ini akan menganalisis manajemen risiko likuiditas BPR di Tangerang melalui manajemen aset, leverage dan kecukupan modal.

\section{B. TINJAUAN PUSTAKA DAN PERUMUSAN HIPOTESIS}

\section{Manajemen Risiko Likuiditas}

Risiko likuiditas dapat didefinisikan sebagai risiko ketidakmampuan untuk melikuidasi secara tepat waktu dengan harga yang wajar (Muranaga \& Ohsawa, 2002).Peraturan Bank Indonesia (PBI) No.11/25/2009, pengertian resiko likuiditas adalah risiko bank akibat ketidakmampuan bank memenuhi kewajiban bank yang telah jatuh tempo dari pendanaan arus kas dan atau aset yang likuid tanpa menggangu aktivas bank sehari-hari.

Manajemen risiko likuiditas merupakan komponen penting dari kerangka manajemen risiko dari keseluruhan industri jasa keuangan, khususnya lembaga keuangan (Majid, 2003). Idealnya, sebuah bank yang dikelola dengan baik harus memiliki mekanisme yang jelas untuk identifikasi, pengukuran, pemantauan dan mitigasi risiko likuiditas. Sebuah sistem yang mapan membantu bank dalam mengidentifikasi secara tepat waktu sumber risiko likuiditas untuk menghindari kerugian.Manajemen risiko likuiditas merupakan komponen penting dari Kerangka manajemen risiko dari keseluruhan industri jasa keuangan, khususnya lembaga keuangan (Majid, 2003).

\section{Perumusan Hipotesis}




\section{Hubungan Kecukupan Modal dengan Likuiditas}

Kecukupan modal dalam penelitian diukur menggunakan Capital Adequacy Ratio. Capital Adequacy Ratio (CAR) adalah rasio yang menunjukkan besarnya kecukupan modal yang dimiliki bank. Semakin efisien modal bank yang digunakan untuk menunjang aktivitas operasional mengakibatkan bank mampu meningkatkan pemberian kredit sehingga akan mengurangi tingkat risiko bank (Syafitri, 2011). Semakin tinggi CAR semakin baik kondisi perbankan. Penelitian yang dilakukan oleh Akhtar et al. (2011) menemukan bahwa CAR tidak berpengaruh terhadap likuiditas pada Bank Syariah.

Berbeda hasil penelitian yang dilakukan oleh Iqbal (2012) dengan temuan CAR berpengaruh terhadap likuiditas pada Bank Konvensional dan Bank Islam. Penelitian Ahmed at al. (2011), Nasiruddin (2005), dan Prayudi (2011) menghasilkan temuan bahwa CAR berpengaruh terhadap likuiditas. Dari beberapa penelitian terdahulu tersebut dapat dirumuskan hipotesis sebagai berikut:

$\mathrm{H}_{1}$ : Kecukupan Modal berpengaruh terhadap risiko likuiditas

\section{Kerangka Penelitian}

Penelitian ini dilakukan untuk menguji secara simultan maupun parsial pengaruh Kecukupan Modal $\left(\mathrm{X}_{3}\right)$ terhadap Risiko Likuiditas (Y). Sebagai ilustrasi dari penjelasan di atas dapat digambarkan sebagai berikut:

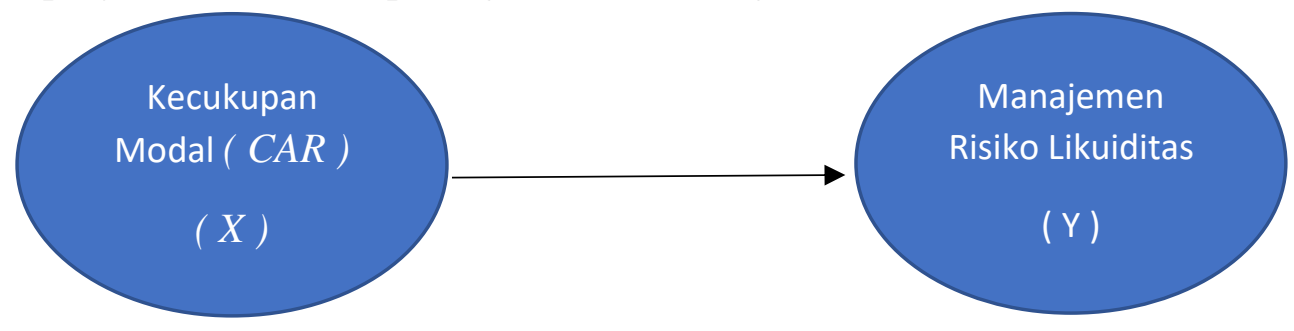

Gambar 1 kerangka pemikiran

\section{METODE PENELITIAN}

\section{Populasi, Sampel, dan Teknik Pengambilan Sampel}

Populasi penelitian adalah seluruh Bank Perkreditan Rakyat (BPR) yang ada di Kota Tangerang. Berdasarkan studi pendahuluan, jumlah BPR per Desember 2016 sebanyak 20 BPR. Sampel dalam penelitian ini diambil dengan teknik exhaustive sampling dimana semua populasi terjangkau digunakan sebagai sampel penelitian. Sampel merupakan seluruh BPR yang berada di Kota Tangerang sebanyak 20 BPR.

\section{Variable Penelitian, Definisi Operasional, dan Pengukuran}


Ada dua kelompok variabel yang digunakan dalam penelitian ini. Variabel terikat dalam penelitian ini adalah risiko likuiditas diukur dengan current ratio. Variabel bebas dalam penelitian ini kecukupan modal diukur dengan capital adequacy ratio ( CAR ).

\section{Tabel 3.1}

Definisi Operasional dan Pengukuran Variabel

\begin{tabular}{|c|c|c|c|}
\hline No & Variabel & Definisi Operasional & Pengukuran \\
\hline 1 & $\begin{array}{l}\text { Risiko } \\
\text { Likuditas }\end{array}$ & $\begin{array}{l}\text { Kemampuan } \\
\text { perusahaan untuk } \\
\text { memenuhi kewajiban } \\
\text { jangka pendeknya yang } \\
\text { segera harus dipenuhi. }\end{array}$ & Current Ratio $=\frac{\text { Aktiva Lancar }}{\text { Hutang Lancar }} \times 100 \%$ \\
\hline 2 & $\begin{array}{l}\text { Kemampuan bank untuk } \\
\text { Kenutupi penurunan } \\
\text { aktivanya sebagai akibat } \\
\text { dari kerugian-kerugian } \\
\text { bank yang disebabkan } \\
\text { oleh aktiva yang berisiko }\end{array}$ & Capial Adequacy Ratio $=\frac{\text { Modal Sendiri }}{\text { Modaliva }} \times 100 \%$ \\
\hline
\end{tabular}

\section{Metode Analisis}

Untuk mengetahui pengaruh kecukupan modal terhadap risiko likuiditas digunakan metode analisis kuantitatif yaitu dengan menggunakan data panel, yaitu kombinasi antara runtut waktu (time series) dan antar ruang (cross section). Alat pengolahan data menggunakan program Eviews 9.

\section{A. Model Data Panel}

Menurut Gujarati (2012) dalam model data panel, persamaan model dengan menggunakan data cross section yaitu:

$$
Y_{t}=\beta_{0}+\beta_{1} X_{1}+e_{1} ; I=1,2, \ldots N
$$

Dimana $N$ adalah banyaknya data cross section.

Sedangkan persamaan model time series adalah sebagai berikut:

$Y_{t}=\beta_{0}+\beta_{1} X_{1}+e_{1} ; I=1,2, \ldots T$

Dimana $T$ adalah banyaknya data time series.

Datapanel merupakan data gabungan time series dengan cross section maka model dapat ditulis:

$Y_{t}=\beta_{0}+\beta_{1} X_{1}+e_{i t} ; i=1,2, \ldots N ; t=1,2, \ldots T$

dimana :

$N=$ banyaknya observasi

$T=$ banyaknya waktu 
$N \times T=$ banyaknya data panel

\section{B. Pendekatan dalam Mengestimasi Model Regresi dengan Data Panel}

Menurut Widarjono (2009) ada 3 teknik pendekatan mendasar yang digunakan dalam mengestimasi model regresi dengan data panel, yaitu:

1. Model Pooled Least Square (Common Effect)

Metode pendekatan ini tidak memperhatikan dimensi individu maupun waktu. Diasumsikan bahwa perilaku data antar individu sama dalam berbagai kurun waktu. Model ini hanya menggabungkan kedua data tersebut tanpa melihat perbedaan antar waktu dan individu sehingga dapat dikatakan bahwa model ini sama halnya dengan metode OLS (Ordinary Least Square) karena menggunakan kuadrat kecil biasa. Pada beberapa penelitian data panel, model ini seringkali tidak pernah digunakan sebagai estimasi utama karena sifat dari model ini yang tidak membedakan perilaku data sehingga memungkinkan terjadinya bias, namun model ini digunakan sebagai pembanding dari kedua pemilihan model lainnya.

2. Model Pendekatan Efek Tetap (Fixed Effect)

Pendekatan model ini menggunakan variabel dummy yang dikenal dengan sebutan model efek tetap (fixed effect) atau Least Square Dummy Variable atau disebut juga Covariance Model. Pada metode fixed effect, estimasi dapat dilakukan dengan tanpa pembobot (no weighted) atau Least Square Dummy Variable (LSDV) dan dengan pembobot (cross section weight) atau General Least Square (GLS). Tujuan dilakukannya pembobotan adalah untuk mengurangi heterogenitas antar unit cross section. Penggunaan model ini tepat untuk melihat perubahan perilaku data dari masing-masing variabel sehingga data lebih dinamis dalam mengintrepetasi data.

3. Model Pendekatan Efek Acak (Random Effect).

Model data panel pendekatan ketiga yaitu model efek acak (random effect). Dalam model fixed effect memasukkan dummy bertujuan mewakili ketidaktahuan kita tentang model yang sebenarnya. Namum membawa konsekuensi berkurangnya derajat kebebasan (degree of freedom) sehingga pada akhirnya mengurangi efisiensi parameter. Untuk mengatasi masalah tersebut dapat digunakan variabel gangguan (error term) yang dikenal dengan random effect. Model ini mengestimasi data panel dimana variabel gangguan mungkin saling berhubungan antar waktu dan antar individu. 


\section{Pengujian Hipotesis}

\section{Uji R-Square $\left(\mathbf{R}^{2}\right)$}

Koefisiensi determinasi $\left(\mathrm{R}^{2}\right)$ menginformasikan baik atau tidaknya model regresi yang terestimasi. Angka tersebut dapat mengukur seberapa dekat garis regresi yang terestimasi dengan data sesungguhnya. Artinya, nilai tersebut mencerminkanseberapa besar variasi dari varibael terikat $\mathrm{Y}$ dapat diterangkan oleh variabel bebas $\mathrm{X}$. Semakin besar $\mathrm{R}^{2}$, maka semakin baik dari model regresi yang diperoleh. Baik atau tidaknya suatu persamaan regresi ditentukan oleh $\mathrm{R}^{2}$-nya yang mempunyai nilai antara nol sampai satu.

Ketentuannya adalah bila nilai koefisien determinasi sama dengan 0 $\left(\mathrm{R}^{2}=0\right)$ artinya variasi dari $\mathrm{Y}$ tidak dapat diterangkan oleh $\mathrm{X}$ sama sekali. Sedangkan bila $\mathrm{R}^{2}=1$ artinya variasi dari $\mathrm{Y}$ secara keseluruhan dapat diterangkan oleh $\mathrm{X}$. Dengan kata lain, bila $\mathrm{R}^{2}=1$, maka semua titik-titik pengamatan berada tepat pada garis regresi.

\section{Uji Keseluruhan (Uji-F)}

Pengujian hipotesis dilakukan dengan uji-F pada tingkat kepercayaan 95 persen dan derajat kebebasan df $1=\mathrm{k}$ dan $\mathrm{df} 2=\mathrm{n}-\mathrm{k}-1$.

$\mathrm{H}_{0}: \beta_{1}=\beta_{2}=\beta_{3}=0$, artinya secara bersama-sama tidak ada pengaruh variabel bebas terhadap variabel terikat.

Ha: $\beta_{1} \neq \beta_{2} \neq \beta_{3} \neq 0$, artinya secara bersama-sama ada pengaruh variabel bebas terhadap variabel terikat.

Apabila:

F-statistik $<$ F-tabel : $\mathrm{H}_{0}$ diterima dan Ha ditolak

F-statistik > F-tabel : $\mathrm{H}_{0}$ ditolak dan Ha diterima

Jika $\mathrm{H}_{0}$ diterima, berarti variabel bebas tidak berpengaruh nyata terhadap variabel terikat. Sebaliknya, jika $\mathrm{H}_{0}$ ditolak berarti variabel bebas berpengaruh nyata terhadap variabel terikat.

\section{Uji Parsial (Uji-t statistik)}

Pengujian hipotesis untuk setiap koefisien regresi dilakukan dengan uji-t statistik pada tingkat kepercayaan 95 persen dan dengan derajat kebebasan $\mathrm{df}=\mathrm{n}-\mathrm{k}-1$.

$H_{0}: \beta_{1}=0$ : tidak berpengaruh

$\mathrm{Ha}: \beta_{1} \neq 0$ : berpengaruh

Apabila: 
t-statistik $\leq \mathrm{t}$-tabel : $\mathrm{H}_{0}$ diterima dan Ha ditolak

$\mathrm{t}$-statistik $\geq \mathrm{t}$-tabel : $\mathrm{H}_{0}$ ditolak dan Ha diterima

\section{HASIL DAN PEMBAHASAN}

1. Populasi dan Sampel

Populasi yang digunakan dalam penelitian ini adalah seluruh Bank Perkreditan Rakyat ( BPR ) yang terdaftar di Otoritas Jasa Keuangan yang terdapat di Kota Tangerang yang berjumlah 20 perusahan selama tahun 2011-2016.

2. Estimasi Model Regresi Data Panel

Pemodelan yang dilakukan dalam penelitian ini menggunakan data Risiko likuiditas yang diukur dengan current ratio sebagai variabel terikat dan data Variabel bebas dalam dan kecukupan modal diukur dengan capital adequacy ratio

a. Common Effect Model (CEM)

Pemodelan menggunakan Common Effect Model dilakukan dengan menggunakan bantuan program Eviews 9.0 dengan hasil estimasi sebagai berikut:

Tabel 4.1

Hasil Common Effect Model (CEM)

\begin{tabular}{lllll}
\hline \hline Variable & \multicolumn{2}{c}{ Coefficient Std. Error } & t-Statistic & Prob. \\
\hline \hline C & 3.248054 & 0.514148 & 6.317353 & 0.0000 \\
CAR & 0.002305 & 0.001526 & 1.510732 & 0.1322
\end{tabular}

Sumber : Hasil olah data

b. Fixed Effect Model (FEM)

Pemodelan menggunakan Fixed Effect Model dilakukan dengan menggunakan bantuan program Eviews 9.0 dengan hasil estimasi sebagai berikut:

Tabel 4.2

Hasil Fixed Effect Model (FEM)

\begin{tabular}{lllll} 
Variable & \multicolumn{2}{l}{ Coefficient Std. Error } & t-Statistic & Prob. \\
\hline \hline C & 2.469222 & 0.594012 & 4.156858 & 0.0000 \\
CAR & -0.001208 & 0.001175 & -1.027977 & 0.3052
\end{tabular}

Sumber : Hasil olah data

c. Random Effect Model (REM) 
Pemodelan menggunakan Random Effect Model dilakukan dengan menggunakan bantuan program Eviews 9.0 dengan hasil estimasi sebagai berikut:

Tabel 4.3

Hasil Random Effect Model (REM)

\begin{tabular}{lllll}
\hline \hline Variable & \multicolumn{2}{c}{ Coefficient Std. Error } & t-Statistic & Prob. \\
\hline \hline C & 2.469222 & 0.594012 & 4.156858 & 0.0000 \\
CAR & -0.001208 & 0.001175 & -1.027977 & 0.3052
\end{tabular}

Sumber : Hasil olah data

3. Teknik Pemilihan Model Regresi Data Panel

a. Uji Chow

HO : Model mengikuti Common Effect Model ( CEM) jika probabilitas (Prob.) cross-section $\mathrm{F}$ dan cross-section chi-square $>\alpha(0,05)$

Ha : Model mengikuti Fixed Effect Model ( FEM ) jika probabilitas (Prob.) cross-section $\mathrm{F}$ dan cross-section chi-square $<\alpha(0,05)$

Berikut hasil Uji Chow dengan menggunakan program eviews 9.0 :

Tabel 4.4

Hasil Uji Chow

\begin{tabular}{llll}
\hline \hline Effects Test & Statistic & d.f. & Prob. \\
\hline \hline Cross-section F & 7.896033 & $(48,193)$ & 0.0000 \\
Cross-section Chi-square & 266.18405348 & 0.0000 \\
\hline \hline
\end{tabular}

Sumber: Hasil Olah data

Berdasarkan perhitungan diatas nilai probabilitas cross-section $\mathrm{F}$ dan cross-section chi-square 0,0000 dan 0,0000 yang nilainya $<\alpha(0,05)$, maka dapat disimpulkan bahwa Fixed Effect Model ( FEM ) lebih layak digunakan dibandingan dengan Common Effect Model ( CEM ).

b. Uji Hausman

HO : Model mengikuti Random Effect Model (REM) jika probabilitas (Prob.) cross-section random $>\alpha(0,05)$

Ha : Model mengikuti Fixed Effect Model (FEM) jika probabilitas (Prob.) crosssection random $<\alpha(0,05)$ 
Berikut hasil Uji Hausman dengan menggunakan program eviews 9.0 :

Tabel 4.5

Hasil Uji Hausman

\begin{tabular}{llll}
\hline \hline \multirow{2}{*}{ Test Summary } & Chi-Sq. & & \\
& Statistic & Chi-Sq. d.f. Prob. \\
\hline \hline Cross-section random & 8.867138 & 3 & 0.0311 \\
\hline \hline
\end{tabular}

Sumber : Hasil Olah Data

Berdasarkan hasil perhitungan diatas nilai probabilitas cross-section random 0,0311 yang nilainya < $\alpha(0,05)$, maka dapat disimpulkan bahwa Fixed Effect Model ( FEM ) lebih layak digunakan dibandingan dengan Random Effect Model ( REM).

c. Uji Lagrange Multiplier

HO : Model mengikuti Common Effect Model ( CEM ) jika Probabilitas (Prob.) Breush-Pagan > a $(0,05)$

Ha : Model mengikuti Random Effect Model ( REM ) jika Probabilitas (Prob.) Breush-Pagan < $\alpha(0,05)$

Berikut hasil Uji Hausman dengan menggunakan program eviews 9.0 :

Table 4.6

Hasil Uji Lagrange Multiplier

Test Hypothesis

Cross-section Time Both

\begin{tabular}{lccc}
\hline \hline Breusch-Pagan & 145.1441 & 1.292726 & 146.4368 \\
& $(0.0000)$ & $(0.2555)$ & $(0.0000)$
\end{tabular}

Sumber Hasil Olah Data

Berdasarkan hasil perhitungan diatas nilai Probabilitas (Prob.) BreushPagan 0,0000 yang nilainya < a $(0,05)$, maka dapat disimpulkan bahwa Random Effect Model ( REM ) lebih layak digunakan dibandingan dengan Common Effect Model ( CEM ).

d. Kesimpulan Model Regresi Data Panel Yang Digunakan

Tabel 4.7

Kesimpulan Model Regresi 


\begin{tabular}{|l|l|l|l|}
\hline No & Metode & Pengujian & Hasil \\
\hline 1 & Uji Chow & CEM vs FEM & FEM \\
\hline 2 & Uji Hausman & REM vs FEM & FEM \\
\hline 3 & Uji Lagrange Multiplier & CEM vs REM & REM \\
\hline
\end{tabular}

Berdasarkan hasil ketiga pengujian yang sudah dilakukan maka dapat disimpulkan bahwa Model Regresi Data Panel yang akan digunakan dalam Uji Hipotesis dan persamaan Regresi Data Panel adalah model Fixed Effect Model (FEM).

4. Uji Asumsi Klasik

a. Uji Multikolinearitas

Dari hasil output dengan menggunakan Eviews 9.0 hasil uji multikolineritas sebesar -0.8092806 dapat dilihat tidak ada variabel independen yang memiliki nilai lebih dari 0,8 , sehingga dapat disimpulkan tidak terjadi multikolinearitas dalam model regersi.

b. Uji Heteroskedastisitas

Uji Heteroskedastisitas perlu dilakukan untuk mengetahui ada atau tidaknya ketidaksamaan variabel dari residual model regresi data panel.

Tabel 4.7

Hasil Uji Heteroskedastisitas

\begin{tabular}{lccl}
\hline \hline Test & Statistic & d.f. & Prob. \\
\hline \hline Breusch-Pagan LM & 1855.749 & 1176 & 0.0000
\end{tabular}

Sumber : Hasil Olah Data

Jika nilai Prob. Breusch-Pagan LM lebih besar dari tingkat a 0,05, maka HO diterima yang artinya tidak terjadi Heteroskedastisitas. Apabila nilai Prob. Breusch-Pagan LM lebih kecil dari tingkat $\alpha 0,05$, maka Ha diterima yang artinya terjadiHeteroskedastisitas.

Dari output diatas dapat dilihat nilai nilai Prob. Breusch-Pagan LM sebesar $0.0000<0,05$ maka dengan demikian dapat disimpulkan bahwa model regresi data panel terjadi Heteroskedastisitas.

5. Uji Hipotesis

a. Uji F

Tabel 4.8

Hasil Uji F

Variable Coefficient Std. Error t-Statistic Prob. 
Effects Specification

Cross-section fixed (dummy variables)

\begin{tabular}{|c|c|c|c|}
\hline R-squared & 0.680 & Mean dependent var & 2.228163 \\
\hline Adjusted R-squared & 0.5 & ent var & 5.472998 \\
\hline S.E. of regression & 3.478850 & Akaike info criterion & 5.517202 \\
\hline Sum squared resid & 2335.763 & Schwarz criterion & 6.260327 \\
\hline Log likelihood & $-623 . \varepsilon$ & Hannan-C & 5.816458 \\
\hline Statistic & 8.056969 & Durbin-Watson stat & 1.470622 \\
\hline 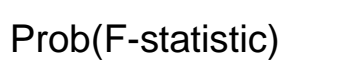 & 0.000000 & & \\
\hline
\end{tabular}

Sumber : Hasil Olah Data

Jika F-statistic < F Tabel, maka H0 diterima yang artinya variabel independen $(X)$ secara bersama-sama tidak berpengaruh terhadap variabel dependen (Y). Namun sebaliknya, jika F-statistic > F Tabel, maka Ha diterima artinya variabel independen $(X)$ secara bersama-sama berpengaruh terhadap variabel dependent $(\mathrm{Y})$.

Pada hasil output diatas menunjukan bahwa nilai F-statistic sebesar 8,056969, sementara $F$ Tabel dengan tingkat $\alpha=5 \%$, df1 $(k-1)=5$ dan df2 $(n-k)=$ 241 didapat nilai $\mathrm{F}$ Tabel sebesar 2,26. Dengan demikian F-statistic $(8,056969)>$ F Tabel $(2,26)$ dan nilai Prob (F-Statistic) 0,0000 $<0,005$ maka dapat disimpulkan bahwa variabel-variabel independen dalam penelitian ini yang terdiri dari dan CAR secara bersama-sama memiliki pengaruh terhadap Kecukupan modal.

b. Uji R-squared (Koefisien Determinasi)

Hasil Koefisien Determinasi menjelaskan seberapa jauh kemampuan model regresi dalam enerangkan variasi variabel bebas mempengaruhi variabel terikat. Nilai R-squared akan menunjukan seberapa besar $\mathrm{X}$ akan mempengaruhi pergerakan $\mathrm{Y}$.

Berikut hasil perhitungan R-squared dengan menggunakan program Eviews 9.0:

Tabel 4.9

Hasil Uji R-squared

\begin{tabular}{llll}
\hline \hline R-squared & 0.680414 & Mean dependent var & 2.228163 \\
Adjusted R-squared & 0.595963 & S.D. dependent var & 5.472998 \\
S.E. of regression & 3.478850 & Akaike info criterion & 5.517202 \\
Sum squared resid & 2335.763 & Schwarz criterion & 6.260327
\end{tabular}


Log likelihood $\quad-623.8573$ Hannan-Quinn criter. 5.816458

F-statistic $\quad 8.056969$ Durbin-Watson stat 1.470622

Prob(F-statistic) $\quad 0.000000$

Sumber : Hasil Olah data

Hasil output diatas menunjukan bahwa R-squared sebesar 0.680414 , artinya bahwa variasi perubahan naik turunnya Kecukupan Modal dapat dijelaskan oleh CAR sebesar $68 \%$, sementara sisanya yaitu sebesar $32 \%$ dijelaskan oleh variabel-variabel lain yang tidak diteliti dalam penelitian ini.

c. Uji t

Jika nilai $t$-statistic $<\mathrm{t}$ tabel, maka $\mathrm{HO}$ diterima yang artinya variabel independen $(\mathrm{X})$ secara parsial tidak berpengaruh terhadap variabel terikat $(\mathrm{Y})$. Namun sebaliknya, jika nilai $t$-statistic $>\mathrm{t}$ tabel, maka Ha diterima artinya variabel independen $(X)$ secara parsial berpengaruh terhadap variabel terikat $(Y)$.

Berdasarkan probabilitas

Jika nilai prob. $>\propto \alpha, 05$, maka $\mathrm{HO}$ diterima yang artinya variabel independen (X) secara parsial tidak berpengaruh terhadap variabel terikat (Y). Namun sebaliknya, jika nilai prob. $<\alpha$ 0,05, maka Ha diterima artinya variabel independen (X) secara parsial berpengaruh terhadap variabel terikat $(Y)$.

Tabel 4.10

Hasil Uji t

\begin{tabular}{|l|l|l|l|l|}
\hline Variable & Coefficient & Std. Error & t-Statistic & Prob. \\
\hline CAR & -0.001208 & 0.001175 & 3.027977 & 0.0052 \\
\hline
\end{tabular}

Sumber : Hasil Olah Data

Nilai t-statistic CAR sebesar -1.027977 , sementara t tabel dengan tingkat $\alpha=5 \%, \mathrm{df}(n-k)=241$ didapat nilai $t$ tabel sebesar 2.596383. Dengan demikian t-statistic kecukupan modal (3.027977) > t tabel (2.596383) dan nilai Prob. $0.0052<0.05$ maka dapat disimpulkan bahwa hipotesis H3 ditolak, berarti CAR atau Kecukupan Modal berpengaruh tidak signifikan terhadap Manajemen Risiko Likuiditas Bank Perkreditan Rakyat yang ada di Tangerang.

CAR merupakan indikator terhadap kemampuan bank untuk menutupi penurunan aktivanya sebagai akibat dari kerugian bank yang disebabkan oleh aktiva yang berisiko (Syafitri, 2011). Hal ini berarti semakin tinggi nilai CAR suatu bank maka semakin tinggi pula tingkat likuiditas bank tersebut. Dengan thitung yang positif menunjukkan bahwa bank memiliki kemampuan dalam 
mempertahankan modalnya dan dapat mengontrol resiko-resiko yang dapat mempengaruhi besarnya modal bank dan likuiditas bank

\section{KESIMPULAN DAN SARAN}

\section{Kesimpulan}

Berdasarkan hasil penelitian yang telah dilakukan dapat diambil beberapa kesimpulan sebagai berikut:

1. Dari Uji $t$ untuk variable Kecukupan Modal terhadap Risiko Likuiditas menyimpulkan bahwa dalam penelitian ini berpengaruh signifikan terhadap risiko likuiditas.

2. Uji $F$ menunjukkan bahwa variabel kecukupan modal secara bersama-sama berpengaruh terhadap Risiko Likuiditas bank.

3. Dari nilai adjusted $\mathrm{R}$ square diketahui variasi variabel Risiko Likuiditas sebagai variabel dependen dapat dijelaskan oleh variasi variabel independennya yaitu manajemen asset, leverage dan kecukupan modal sebesar $68 \%$ sedangkan sisanya yaitu sebesar $32 \%$ dipengaruhi oleh variabel lain di luar penelitian ini.

\section{Saran}

Berdasarkan hasil penelitian dan beberapa keterbatasan penelitian di atas, maka penulis memberikan saran untuk penelitian lebih lanjut sebagai berikut :

1. Likuiditas perbankan dalam penelitian ini diukur dengan menggunakan rasio modal dibagi dengan total asset sesuai dengan penelitian Ahmed (2011). Untuk penelitian selanjutnya diharapkan peneliti dapat menggunakan proksi lain dalam mengukur likuiditas perbankan karena setiap pengukuran yang digunakan akan menghasilkan temuan yang berbeda.

2. Variabel yang digunakan dalam penelitian ini terbatas pada delapan variabel internal bank. Untuk penelitian selanjutnya disarankan untuk meneliti variabelvariabel lain yang berpengaruh terhadap likuiditas bank baik variabel internal maupun variabel eksternal bank, contohnya tingkat inflasi, PDB, tingkat pengangguran, suku bunga Bank Indonesia, dan lain-lain.

3. Penelitian selanjutnya diharapkan dapat meneliti jenis bank lain, misalnya BPR, BPD, dan bank syariah.

\section{DAFTAR PUSTAKA}

5.

Ahmed, Neveed., et al. 2011. Risk Management Practices and Islamic Banks: An Empirical Investigation from Pakistan. Interdisciplinary Journal of Research in Business, 1(6), 50-57.

Adams, D.W. and Vogel, R.C. 1986."Rural financial markets in low-income countries: recent contoversies and lessons", World Development. Vol. 14 No. 4. pp. 477-87. 
Ajija, Shochrul R. 2011. Cara Cerdas Menguasai EViews.Salemba Empat. Jakarta. Akhtar, S. 2007. Pakistan: changing risk management paradigm - perspective of the regulator. ACCA Conference - CFOs: The Opportunities and Challenges Ahead, ( $p$. 8). Karachi.

Bambang, Riyanto, 2001. Dasar-Dasar Pembelanjaan Perusahaan. EdisiKeempat, Cetakan Ketujuh. BPFE Yogyakarta.

Barrell, R., Davis, E.P., Fic, T., Holland, D., Kirby, S. and Liadze, I. 2009. "Optimal Regulation of Bank Capital and Liquidity: How to Calibrate New International Standards", FSA Occasion Paper No 38.

Brigham, Eugene F., \& Houston, Joel F. 2009. Dasar-Dasar Manajemen Keuangan. (Alih bahasa: Ali Akbar Yulianto). Salemba Empat. Jakarta.

Crowe, K. 2009. Liquidity risk management - more important than ever. Harland Financial Solutions, 3.

Dusuki, A.W. 2008. "Banking for the poor: the role of Islamic banking in microfinance initiatives". Humanomics. Vol.24. No. 1. pp. 49-66.

Dendawijaya, Lukman. 2009. Manajemen Perbankan. Ghalia Indonesia. Jakarta Fahmi, Irham. 2012. Analisis Laporan Keuangan. Cetakan Ke-2. Alfabeta. Bandung. Gujarati, D.N., 2012. Dasar-dasar Ekonometrika. Terjemahan Mangunsong, R.C., buku 2, Edisi 5. Salemba Empat. Jakarta.

Harahap, Sofyan Syafri. 2013.Analisis Kritis Atas Laporan Keuangan. Cetakan Kesebelas. Penerbit Rajawali Pers. Jakarta.

Hasibuan, H. Melayu S.P. 2009. Dasar-dasar Perbankan. Cetakan Kedelapan. PT. Bumi Aksara. Jakarta.

Howells, P. and Bain, K. 1999. The Economics of Money, Banking and Finance, a European Text. Essex CM20 2JE, England: Pearson Education Limited, Edinburgh Gate, Harlow.

lqbal, Anjum. 2012. Liquidity Risk Management: A Comparative Study Between Conventional and Islamic Bank of Pakistan. Global Journal of Management and Business Research, 12 (5), 54-64.

Kasmir. 2012. Analisis Laporan Keuangan. PT.Raja Grafindo Persada. Jakarta.

Majid, A. 2003. Development of liquidity management instruments: challenges and opportunities. International Conference on Islamic Banking: Risk Management Regulation and Supervision, (p. 24). Jakarta - Indonesia.

Muranaga, J., \& Ohsawa, M. 2002. Measurement of liquidity risk in the context of market risk calculation. Working paper, Institute for Monetary and Economic Studies, Bank of Japan, Tokyo. 
Nasirudin. 2005. Faktor-faktor yang Mempengaruhi Loan to Deposit Ratio (LDR) di BPR Wilayah Kerja Kantor Bank Indonesia Semarang. Tesis Universitas Diponegoro Semarang.

Puteh, Anwar. 2013. Pengaruh Current Ratio dan Total Assets Turnover terhadap Return On Equity pada Perbankan Yang Terdaftar Di Bursa Efek Indonesia. Semnas Fekon: Optimisme Ekonomi Indonesia 2013, Antara Peluang dan Tantangan.

Prayudi, Arditya. 2011. Pengaruh Capital Adequacy Ratio (CAR), Non Performing Loan (NPL), BOPO, Return On Asset (ROA) dan Net Interest Margin (NIM) terhadap Loan to Deposit Ratio (LDR). Gunadarma University E-Paper.

Sawir, Agnes. 2009. Analisa Kinerja Keuangan dan Perencanaan Keuangan Perusahaan. PT. Gramedia Pustaka Utama. Jakarta.

Supriadi, Yoyon. 2012. "Meningkatkan Profitabilitas Perusahaan Melalui Manajemen Aset." Jurnal IImiah Kesatuan. Vol. 14, No. 1, hal. 33-42.

Widarjono, Agus. 2009. Ekonometrika Pengantar dan Aplikasinya. Edisi Ketiga. EKONISIA. Yogyakarta. 